\title{
PROCESS DESIGN AND INTEGRATION OF SHALE GAS TO METHANOL
}

An Undergraduate Research Scholars Thesis

by

VICTORIA M. EHLINGER

\author{
Submitted to Honors and Undergraduate Research \\ Texas A\&M University \\ In partial fulfillment of the requirements for the designation as \\ UNDERGRADUATE RESEARCH SCHOLAR
}

Approved by Research Advisor:

Dr. Mahmoud El-Halwagi

May 2013

Major: Chemical Engineering 


\section{TABLE OF CONTENTS}

Page

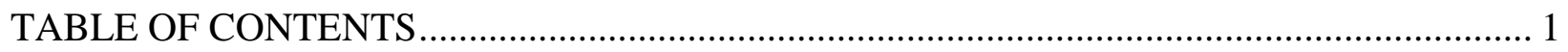

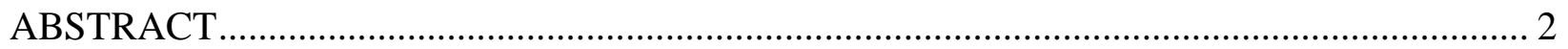

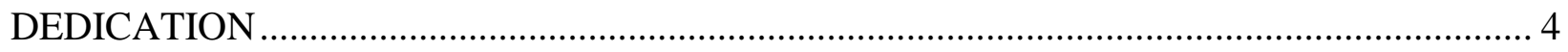

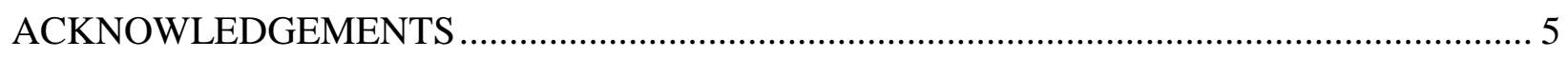

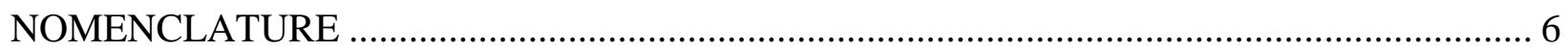

\section{CHAPTERS}

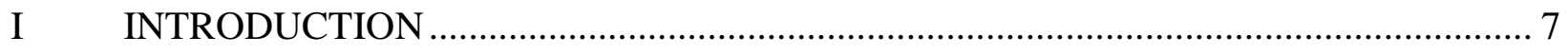

The emerging shale gas industry in the United States ................................................... 8

Natural gas processing ………………………………........................................... 10

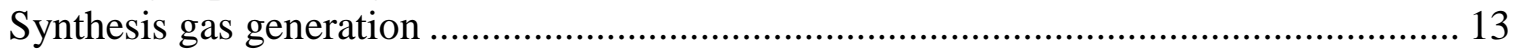

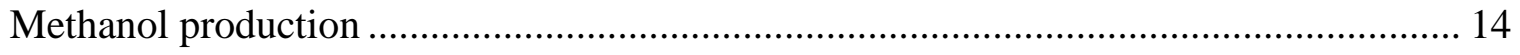

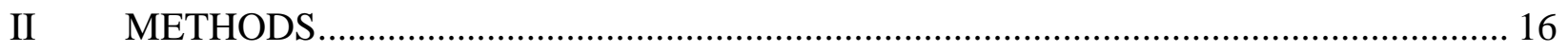

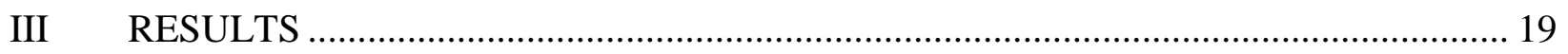

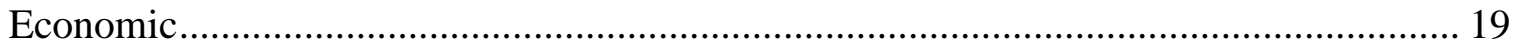

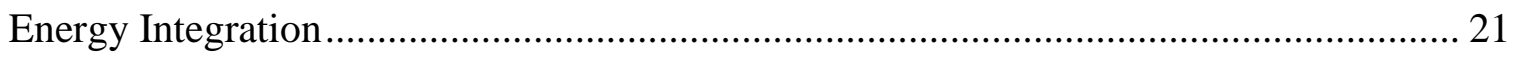

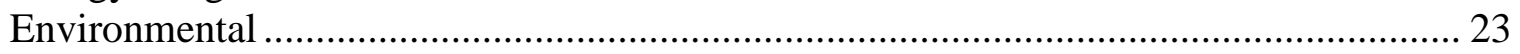

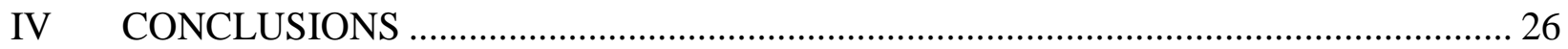

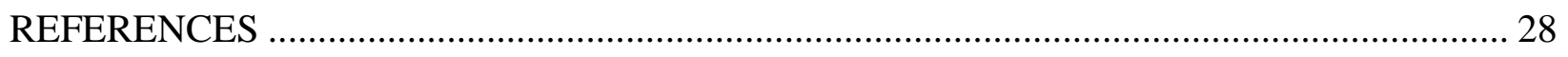

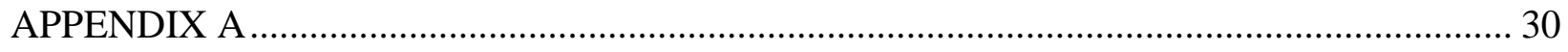

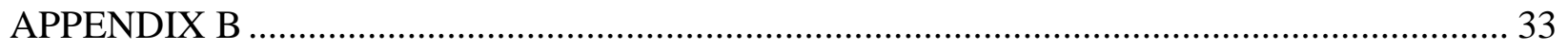

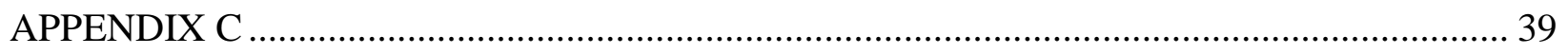

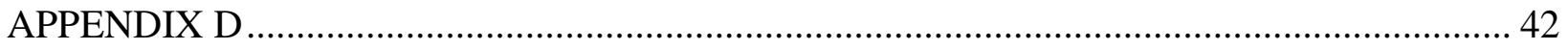




\author{
ABSTRACT \\ Process Design and Integration of Shale Gas to Methanol. (May 2013) \\ Victoria M. Ehlinger \\ Artie McFerrin Department of Chemical Engineering \\ Texas A\&M University \\ Research Advisor: Dr. Mahmoud El-Halwagi \\ Artie McFerrin Department of Chemical Engineering
}

Recent breakthroughs in horizontal drilling and hydraulic fracturing technology have made huge reservoirs of previously untapped shale gas and shale oil formations available for use. These new resources have already made a significant impact on the United States chemical industry and present many opportunities for new capital investments and industry growth. As in conventional natural gas, shale gas contains primarily methane, but some formations contain significant amounts of higher molecular weight hydrocarbons and inorganic gases such as nitrogen and carbon dioxide. These differences present several technical challenges to incorporating shale gas with current infrastructure designed to be used with natural gas. However, each shale presents opportunities to develop novel chemical processes that optimize its composition in order to more efficiently and profitably produce valuable chemical products.

This paper is aimed at process synthesis, analysis, and integration of different processing pathways for the production of methanol from shale gas. The composition of the shale gas feedstock is assumed to come from the Barnett Shale Play located near Fort Worth, Texas, which is currently the most active shale gas play in the US. Process simulation and published data were used to construct a base-case scenario in Aspen Plus. The impact of different processing 
pathways was analyzed. Key performance indicators were assessed. These include overall process targets for mass and energy, economic performance, and environmental impact. Finally, the impact of several factors (e.g., feedstock composition, design and operating variables) is studied through a sensitivity analysis.

The results show a profitable process above a methanol selling price of approximately $\$ 1.50 /$ gal. The sensitivity analysis shows that the ROI depends much more heavily on the selling price of methanol than on the operating costs. Energy integration leads to a savings of $\$ 30.1$ million per year, or an increase in ROI of $2 \%$ points. This also helps offset some of the cost required for the oxygen necessary for syngas generation through partial oxidation. For a sample shale gas composition with high levels of impurities, preprocessing costs require a price differential of $\$ 0.73 / \mathrm{MMB} t u$ from natural gas. The process is also environmentally desirable because shale gas does not lead to higher GHG emissions than conventional natural gas. More water is required for hydraulic fracturing, but some of these concerns can be abated through conservation techniques and regulation. 


\section{DEDICATION}

To my family and friends,

For encouraging me to pursue undergraduate research and supporting me through the entire process. 


\section{ACKNOWLEDGEMENTS}

Thanks to Dr. Mahmoud El-Halwagi for assistance with the process analysis, energy integration, and cost estimation, Kerron Gabriel for assistance with process design and simulation set up, and Mohamed Noureldin for assistance with process design. 


\section{NOMENCLATURE}

C2 - ethane

C3 - propane

DEA - diethanolamine

GHG - greenhouse gas

$\mathrm{kWh}$ - kilowatt hour

LPG - liquefied petroleum gas

MDEA - methyldiethanolamine

MEA - monoethanolamine

$\mathrm{MeOH}$ - methanol

MMscf - million standard cubic feet

MMBtu - million Btu (British thermal unit)

NGL - natural gas liquids

ROI - return on investment

WGS - water-gas shift 


\section{CHAPTER I}

\section{INTRODUCTION}

In order to meet the energy demands of the twenty-first century, engineers and scientists are working to develop new methods of discovering, extracting, and refining fossil fuels including oil, coal, and natural gas. While the development of alternative energy technologies continues and the use of renewable energy sources increases, fossil fuels still fulfill the majority of the United States' energy needs: approximately $85 \%$, with natural gas supplying about $22 \%$ of the total [1].

Natural gas is an odorless, colorless mixture of light hydrocarbons and other gases. The primary component is methane, with the remaining fraction consisting of a mixture of heavier hydrocarbons including ethane and propane. Crude natural gas may also contain other light gases such as nitrogen, helium, and water in small concentrations. Table 1 shows the variability of natural gas concentration and composition due to variations from individual wells.

In light of concerns about environmental pollution and greenhouse gas emissions, consumption of natural gas as a fuel source has grown due to its clean burning nature and high energy content. The main byproducts of combustion of natural gas are carbon dioxide and water, according to the chemical reaction below.

$$
\mathrm{CH}_{4}+2 \mathrm{O}_{2} \rightarrow \mathrm{CO}_{2}+2 \mathrm{H}_{2} \mathrm{O}
$$


Additional byproducts include carbon monoxide, sulfur dioxide, nitrogen oxides, and hydrocarbons; however, these chemicals are present in much lower concentrations in natural gas than in other fossil fuels.

Table 1. Chemical Composition of Conventional Natural Gas [2]

\begin{tabular}{|c|c|c|c|}
\hline Components & Formula & $\begin{array}{c}\text { Typical } \\
(\mathbf{m o l} \%)\end{array}$ & $\begin{array}{c}\text { Extreme } \\
(\mathbf{m o l} \%)\end{array}$ \\
\hline Methane & $\mathrm{CH}_{4}$ & $80-95$ & $50-95$ \\
\hline Ethane & $\mathrm{C}_{2} \mathrm{H}_{6}$ & $2-5$ & $2-20$ \\
\hline Propane & $\mathrm{C}_{3} \mathrm{H}_{8}$ & $1-3$ & $1-12$ \\
\hline Butane & $\mathrm{C}_{4} \mathrm{H}_{10}$ & $0-1$ & $0-4$ \\
\hline $\begin{array}{c}\text { C5 Alkanes and } \\
\text { higher hydrocarbons }\end{array}$ & $\mathrm{C}_{5}+$ & $0-1$ & $0-1$ \\
\hline Carbon Dioxide & $\mathrm{CO}_{2}$ & $1-5$ & $0-99$ \\
\hline Nitrogen & $\mathrm{N}_{2}$ & $1-5$ & $0-70$ \\
\hline Hydrogen Sulfide & $\mathrm{H}_{2} \mathrm{~S}$ & $0-2$ & $0-6$ \\
\hline Oxygen & $\mathrm{O}_{2}$ & 0 & $0-0.2$ \\
\hline Helium & $\mathrm{He}$ & $0-0.1$ & $0-1$ \\
\hline Other inert gases & traces & & \\
\hline
\end{tabular}

Natural gas has an additional advantage over other fossil fuels due to its large domestic availability, which addresses political and economic concerns over dependence on foreign oil supplies. In the United States, $84 \%$ of the natural gas consumed is produced in the country and 97\% is produced in North America [1]. As energy needs continue to rise, natural gas will remain an important resource in the American economy. Natural gas is a key resource for many diverse sectors of the economy, including industrial chemicals and fuels, power generation, transportation fuels, and residential heating.

\section{The emerging shale gas industry in the United States}

As the demand for natural gas continues to rise, new sources and techniques for extracting natural gas are being developed. Unconventional production, which includes but is not limited to 
shale gas production, now accounts for $46 \%$ of the total U.S. production of natural gas [1]. Shale gas production in the United States has been growing consistently over the past decade and Figure 6 shows that shale gas is projected to increase over the next twenty-five years to become the primary source of natural gas produced in the United States. Shale gas includes natural gas sources from low-permeability shale, a sedimentary rock that consists primarily of consolidated clay-sized particles [1]. The low natural permeability of shale has been the limiting factor to the production of shale gas resources because only small volumes of gas flow naturally to a wellbore [1]. However, breakthroughs in modern drilling technology have made it possible to increase gas flow from the shale formation and make development of shale reservoirs economical.

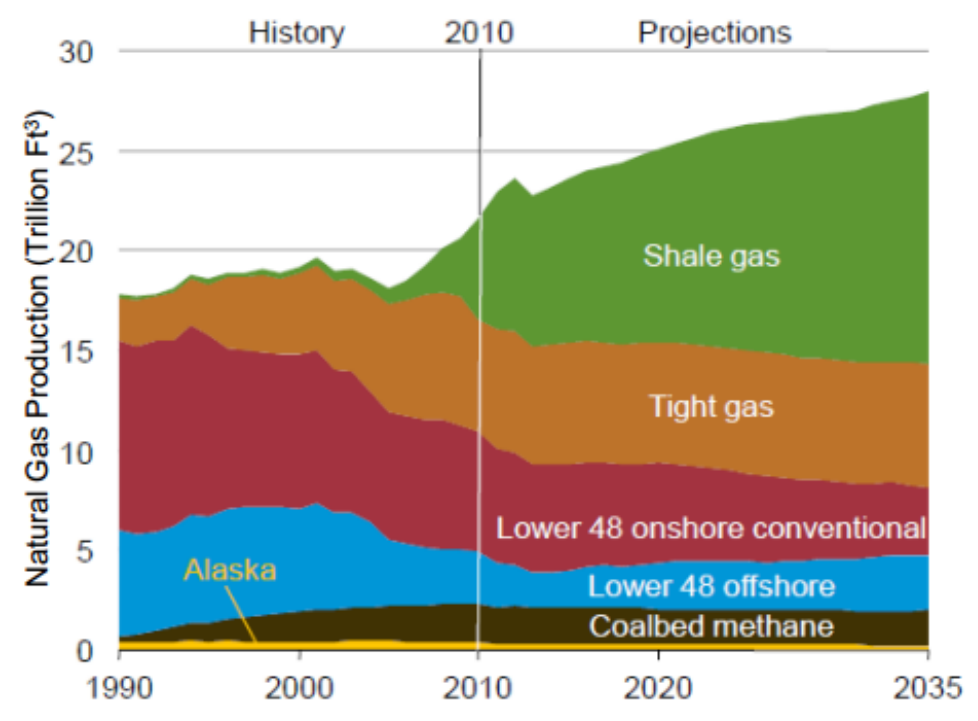

Figure 1. Projections of U.S. Shale Gas Production [3]

The primary difference between modern shale gas development and conventional natural gas development is the extensive use of modern drilling techniques such as horizontal wells and hydraulic fracturing. Drilling of shale gas wells includes both traditional vertical wells as well as horizontal wells. Horizontal well drilling has been an increasingly utilized technique because 
it provides exposure to greater volume of a formation: a single well pad with horizontal wells can access the same reservoir volume as sixteen vertical wells [1]. As a result, fewer drill pads are necessary which also reduces the infrastructure necessary to develop a well. While helping to optimize product recovery and profit, these techniques can also help to reduce the overall environmental impact of gas recovery and production. The hydraulic fracturing technique is also used to increase the well's exposure to natural gas in a rock formation. This is achieved by injection of a fluid under high pressure into the formation, which relieves the internal stresses and causes cracks to form in the rock. Fracturing fluids are typically composed of a mixture of water and sand with chemical additives.

Like in conventional natural gas, the largest fraction of shale gas consists of methane. However, some shale gas formations contain significant amounts of higher molecular weight hydrocarbons, including ethane and propane, as well as other inorganic gases such as nitrogen and carbon dioxide. Compounds in shale gas may not be present in natural gas or may be present only in negligible amounts. These differences present several technical challenges to incorporating the use of shale gas with current infrastructure designed to be used with conventional natural gas. However, each shale gas basin presents many opportunities to develop novel chemical processes that optimize its composition in order to more efficiently and profitably produce valuable chemical products.

\section{Natural gas processing}

Once the crude natural gas has been extracted from underground reservoirs, it must be processed to remove impurities resulting from the drilling process or from the well itself before the gas can 
be used in an industrial or commercial application. Although no national standards exist, each pipeline has strict specifications for heat content, removal of particulate matter, and maximum concentrations of contaminants such as nitrogen, carbon dioxide, and hydrogen sulfide, and natural gas liquids. Some of the most common impurities found in natural gas are listed below in Table 2.

Table 2. Common Impurities In Natural Gas [4]

\begin{tabular}{|l|c|}
\hline Name/Description & Formula \\
\hline Hydrogen Sulfide & $\mathrm{H}_{2} \mathrm{~S}$ \\
\hline Carbon Dioxide & $\mathrm{CO}_{2}$ \\
\hline Water Vapor & $\mathrm{H}_{2} \mathrm{O}$ \\
\hline Sulfur Dioxide & $\mathrm{SO}_{2}$ \\
\hline Nitrogen Oxides & $\mathrm{NO}, \mathrm{NO}_{2}$ \\
\hline Volatile Organic Compounds (VOCs) & \\
\hline Volatile Chlorine Compounds & $\mathrm{HCl}, \mathrm{Cl}_{2}$ \\
\hline Volatile Fluorine Compounds & $\mathrm{HF}, \mathrm{SiF}_{4}$ \\
\hline Basic Nitrogen Compounds & \\
\hline Carbon Monoxide & $\mathrm{CO}$ \\
\hline Carbonyl Sulfide & $\mathrm{COS}$ \\
\hline Carbon Disulfide & $\mathrm{CS}$ \\
\hline Organic Sulfur Compounds & \\
\hline Hydrogen Cyanide & $\mathrm{HCN}$ \\
\hline
\end{tabular}

Processing of natural gas involves three main steps: removal of impurities, dehydration, and separation into light and heavy fractions. In order to prepare the crude gas for processing, acidforming components such as carbon dioxide and hydrogen sulfide must be removed. Next, dehydration is central to the purification process in order to prevent condensation inside pipelines during transport. Similarly, some pipeline standards do not allow for high nitrogen content, so nitrogen is typically removed via a cryogenic separation process and discharged to the atmosphere. Additionally, drilling process water must be treated due to soluble contaminants 
from the gas and particulate matter (i.e. dirt and sand) which infiltrate the water during the drilling process. Figure 2 summarizes the major steps in processing crude natural gas.

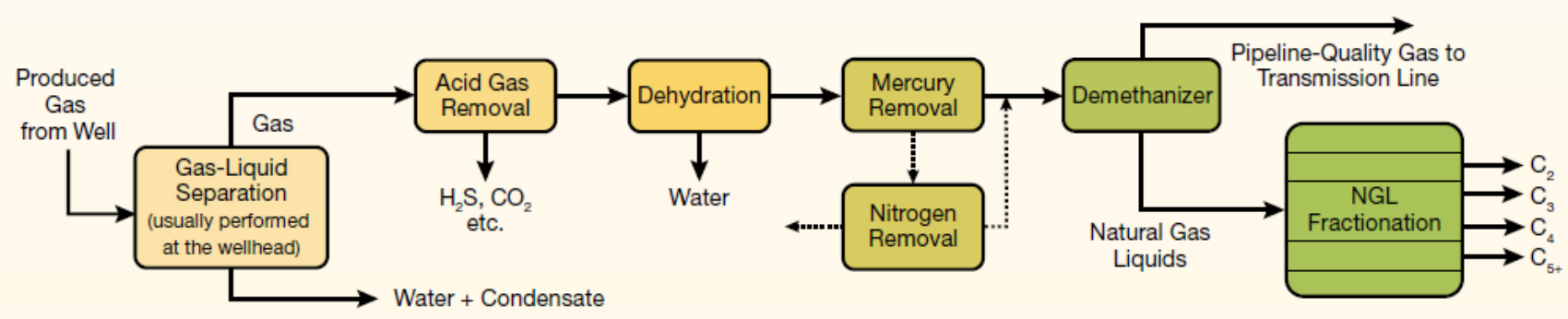

Figure 2. Natural Gas Purification Process [5]

The primary acid forming components in natural gas are carbon dioxide $\left(\mathrm{CO}_{2}\right)$ and hydrogen sulfide $\left(\mathrm{H}_{2} \mathrm{~S}\right)$. Many techniques have been developed to remove these components either together or with selectivity for one component. One technique that serves to remove both components is absorption with an alkanolamine, such as monoethanolamine (MEA), diethanolamine (DEA), or methyldiethanolamine (MDEA).

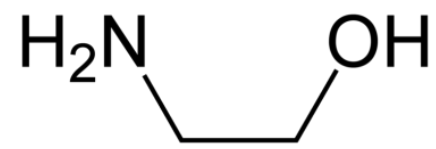

Monoethanolamine (MEA)<smiles>OCCNCCO</smiles>

Diethanolamine (DEA)<smiles>CN(CCO)CCO</smiles>

Methyldiethanolamine (MDEA)

Figure 3. Alkanolamines for Acid-Gas Removal

In the alkanolamine molecules, the hydroxyl group serves to reduce vapor pressure and increase water solubility while the amino group reacts with the acidic gases. Additionally, acid-gas components can be removed from natural gas with physical solvents, catalytic reactions, or other absorbents including ammonium salts and water. 
Water vapor can be removed through adsorption in glycol solution or adsorption on solid desiccants such as silica and alumina. Water can also be used as an absorbent to remove other impurities including major contaminants like ammonia, hydrogen cyanide, sulfur dioxide, and carbon dioxide.

Once impurities are removed from natural gas feedstocks, the hydrocarbons are separated into light and heavy fractions through cooling and partial condensation in a heat exchanger. Modern plants use cryogenic separation to separate propane and butane, also known as liquefied petroleum gas (LPG). In this process, crude gas is cooled and partially condensed under high pressure in a heat exchanger, then expanded, heated and sent to a separation column where the bottoms products consist of the C3 plus products. The light hydrocarbons (ethane and methane) are recycled from the top of the column. Ethane is separated in a similar manner as the LPG process, but with a lower temperature profile.

\section{Synthesis gas generation}

Natural gas serves as an important raw material for the production of many industrial chemicals. One of the most important derivatives of natural gas is synthesis gas, a mixture of carbon monoxide, hydrogen, and nitrogen gases. Synthesis gas is the primary feedstock for the manufacture of several essential commodity chemicals including methanol and ammonia. Purification of crude natural gas is necessary for the production of synthesis gas because components such as sulfur and chlorides poison the nickel catalyst used to generate synthesis gas. Common methods for the generation of synthesis gas include steam reforming, partial 
oxidation, and autothermal reforming. In steam reforming, the primary component of natural gas, methane, reacts with water according to the following endothermal reaction:

$$
\mathrm{CH}_{4}+\mathrm{H}_{2} \mathrm{O}=\mathrm{CO}+3 \mathrm{H}_{2} \quad \Delta \mathrm{Hr}=206 \mathrm{~kJ} / \mathrm{mol}
$$

For partial oxidation, methane is reacted with oxygen from air according to the following exothermal reaction:

$$
\mathrm{CH}_{4}+1 / 2 \mathrm{O}_{2}=\mathrm{CO}+2 \mathrm{H}_{2} \quad \Delta \mathrm{Hr}=-36 \mathrm{~kJ} / \mathrm{mol}
$$

Oxygen present in excess or insufficient amounts will result in the formation of byproducts carbon dioxide and coke (solid carbon). Autothermal reforming combines the previous two techniques by using the energy generated from partial oxidation of hydrocarbons to drive the endothermic reaction in steam reforming.

\section{Methanol production}

Methanol, also known as methyl alcohol or wood alcohol, is a clear, colorless, flammable liquid with the chemical formula $\mathrm{CH}_{3} \mathrm{OH}$. Methanol is among one of the ten most important organic chemicals because it plays a crucial role as a reactant in the manufacture of many other basic chemical compounds. Approximately forty percent of methanol produced goes into formaldehyde production, which occurs by oxidizing methanol in the presence of a copper catalyst resulting in dehydrogenation. Acetic acid can also be produced by reacting methanol with carbon monoxide.

Methanol is typically produced on an industrial scale using a catalytic reaction of synthesis gas at high pressure. In order to produce methanol, first syngas must be generated from the primary feed source using one of the methods discussed in the previous section. Typically, synthesis gas 
is generated from natural gas but current research is developing syngas generation methods utilizing gasification of biomass and gasification of coal. The product stream includes hydrogen and carbon monoxide gas as well as a small amount of unreacted methane, nitrogen, and carbon dioxide.

Equilibrium for methanol formation is favored by low temperatures and high pressures, so the reactor feed conditions are typically $50-100$ atm and $230-260{ }^{\circ} \mathrm{C}$ [6]. The reaction takes place over a $\mathrm{CuO} / \mathrm{ZnO} / \mathrm{Al}_{2} \mathrm{O}_{3}$ catalyst. Methanol synthesis actually occurs as a combination of two reactions in the syngas mixture: the first involving carbon dioxide and hydrogen and the second involving carbon monoxide and water generated in the system. The overall reaction shows a net exothermal conversion of carbon monoxide and hydrogen gases, the primary components of syngas, to liquid methanol.

$$
\begin{array}{ll}
\mathrm{CO}_{(g)}+\mathrm{H}_{2} \mathrm{O}_{(g)}=\mathrm{H}_{2}(g)+\mathrm{CO}_{2(g)} & \Delta \mathrm{H}^{298}=-41 \mathrm{~kJ} / \mathrm{mol} \\
\mathrm{CO}_{2(g)}+3 \mathrm{H}_{2}(g)=\mathrm{CH}_{3} \mathrm{OH}_{(l)}+\mathrm{H}_{2} \underline{\mathrm{O}}_{(g)} & \Delta \mathrm{H}^{298}=-50 \mathrm{~kJ} / \mathrm{mol} \\
\hline \mathrm{CO}_{(g)}+2 \mathrm{H}_{2}(g)=\mathrm{CH}_{3} \underline{\mathrm{OH}}_{(l)} & \Delta \mathrm{H}^{298}=-91 \mathrm{~kJ} / \mathrm{mol}
\end{array}
$$

During this process, some side reactions occur which form impurities including dimethyl ether, methyl formate, and butanol, which must be removed during the final purification of the process. 


\section{CHAPTER II}

\section{METHODS}

Differences in shale gas composition present both challenges and opportunities for innovation in the chemical industry. In this text, the production of methanol from synthesis gas will serve as a sample industrial process to explore some of these possibilities.

Process simulation using ASPEN Plus and published data were used to simulate at 5,000 ton per day methanol plant as the base case. The complete process flow diagrams can be found in Appendix A. The front end of the process, which includes synthesis gas generation through partial oxidation, was modeled using data from Buping, et al. (2010) [7]. For this analysis, the partial oxidation process was selected for the simulation of syngas generation because the reaction is exothermic and does not yield excess hydrogen. The maximum yield for synthesis gas generation occurs when the components are present in a stoichiometric ratio, 2:1. Partial oxidation leads to a $\mathrm{CO} / \mathrm{H}_{2}$ ratio very close to the optimum, about 1.8. However, cost optimization among the three syngas generation processes requires a much more complex analysis which is beyond the scope of this text. The reader may refer to Noureldin et al. (2012) for more information on these design considerations [8]. The methanol reactor was modeled using temperature and pressure conditions cited above and primary chemical reactions and side reactions using the RGIBBS thermodynamic equilibrium model of ASPEN Plus simulation. 
In order to perform the analysis, information was gathered from various sources in order to estimate captial cost and operating costs. Cost of utilities, raw materials, and labor were extracted from literature coupled with simulation results [9-11].

Shale gas preprocessing cost and profit from NGL separation was estimated from literature values and flow rates from the simulator. The preprocessing cost was then used to determine a price differential between natural gas and shale gas. The chemical composition of shale gas represented using values from gas produced from the Barnett Shale play, located in northeast Texas near the Fort Worth area [1]. The area was first developed in the 1980's and was nicknamed the "Grandfather Shale," because it served as the development ground for the modern techniques that made shale gas production economical in the United States. It continues to be the most active shale gas play in the United States, which is why this location was selected as the feed for this study [1]. Values for composition of various wells from the Barnett Shale are shown in Table 3.

Table 3. Barnett Shale Gas Composition [12]

\begin{tabular}{|c|c|c|c|c|c|}
\hline Well & $\mathbf{C 1}$ & $\mathbf{C 2}$ & $\mathbf{C 3}$ & $\mathbf{C O}_{\mathbf{2}}$ & $\mathbf{N}_{\mathbf{2}}$ \\
\hline 1 & 80.3 & 8.1 & 2.3 & 1.4 & 7.9 \\
\hline 2 & 81.2 & 11.8 & 5.2 & 0.3 & 1.5 \\
\hline 3 & 91.8 & 4.4 & 0.4 & 2.3 & 1.1 \\
\hline 4 & 93.7 & 2.6 & 0.0 & 2.7 & 1.0 \\
\hline Avg & 86.8 & 6.7 & 2.0 & 1.7 & 2.9 \\
\hline
\end{tabular}

These data show the wide variability of possible chemical compositions of shale gas formations. While some areas of the Barnett Shale Play are fairly consistent with conventional natural gas sources, others contain much higher concentrations of hydrocarbons, carbon dioxide and 
nitrogen. Data from Well 1 was used in the simulation in order to analyze the scenario with the highest deviation from conventional natural gas composition. 


\section{CHAPTER III}

\section{RESULTS}

\section{Economic}

Detailed stream data from the process simulation can be found in Appendix B. A basis of 7,920 operating hours per year is used. Stream data along with cost estimations were used to generate the following cost and sales estimations.

Table 4. Cost and Sales Estimation

\begin{tabular}{|c|c|c|c|c|c|c|}
\hline \multicolumn{2}{|c|}{ Fixed Capital Investment } & & & & & $\begin{array}{l}\text { MM \$ } \\
1,300.00[13]\end{array}$ \\
\hline \multicolumn{2}{|c|}{$\begin{array}{l}\text { Operating Costs } \\
\text { Raw }\end{array}$} & Flow Rate & & Unit Cost (\$) & & Cost (MM\$/y) \\
\hline \multirow[t]{2}{*}{ Materials } & Natural Gas & 155.8 & MMscf/d & 3.50 & /Mscf [14] & 179.95 \\
\hline & Oxygen & 361394 & $\mathrm{lb} / \mathrm{hr}$ & 0.05 & $/ / \mathrm{lb}[15]$ & 143.11 \\
\hline \multirow[t]{4}{*}{ Utilities } & Heating & 179.95 & MMBtu/hr & 4.00 & /MMBtu & 1.43 \\
\hline & Cooling & 1829.78 & MMBtu/hr & 1.50 & /MMBtu & 21.74 \\
\hline & $\begin{array}{l}\text { Power } \\
\text { Waste }\end{array}$ & 14746 & $\mathrm{kWh}$ & 0.05 & $\mathrm{kWh}$ & 0.24 \\
\hline & Treatment & 94963 & $\mathrm{lb} / \mathrm{hr}$ & 0.53 & /tonne & 0.18 \\
\hline Labor & & & & & & 3.80 \\
\hline Sales & & Flow Rate & & Unit Price (\$) & & $\begin{array}{l}\text { Annual Sales } \\
(\$ M M / y)\end{array}$ \\
\hline & & & & 2.00 & /gal or & 1000.00 \\
\hline Methanol & & 5000 & TPD & 0.30 & $/ \mathrm{lb}$ & \\
\hline
\end{tabular}

A sensitivity analysis was performed to evaluate the ability of the process to withstand changes in feedstock and product values. Figure 4 shows the ROI against methanol price ranging from $\$ 1.00$ - \$4.00 per gallon and natural gas price ranging from $\$ 2.00$ to $\$ 6.00$ per MMBtu. 


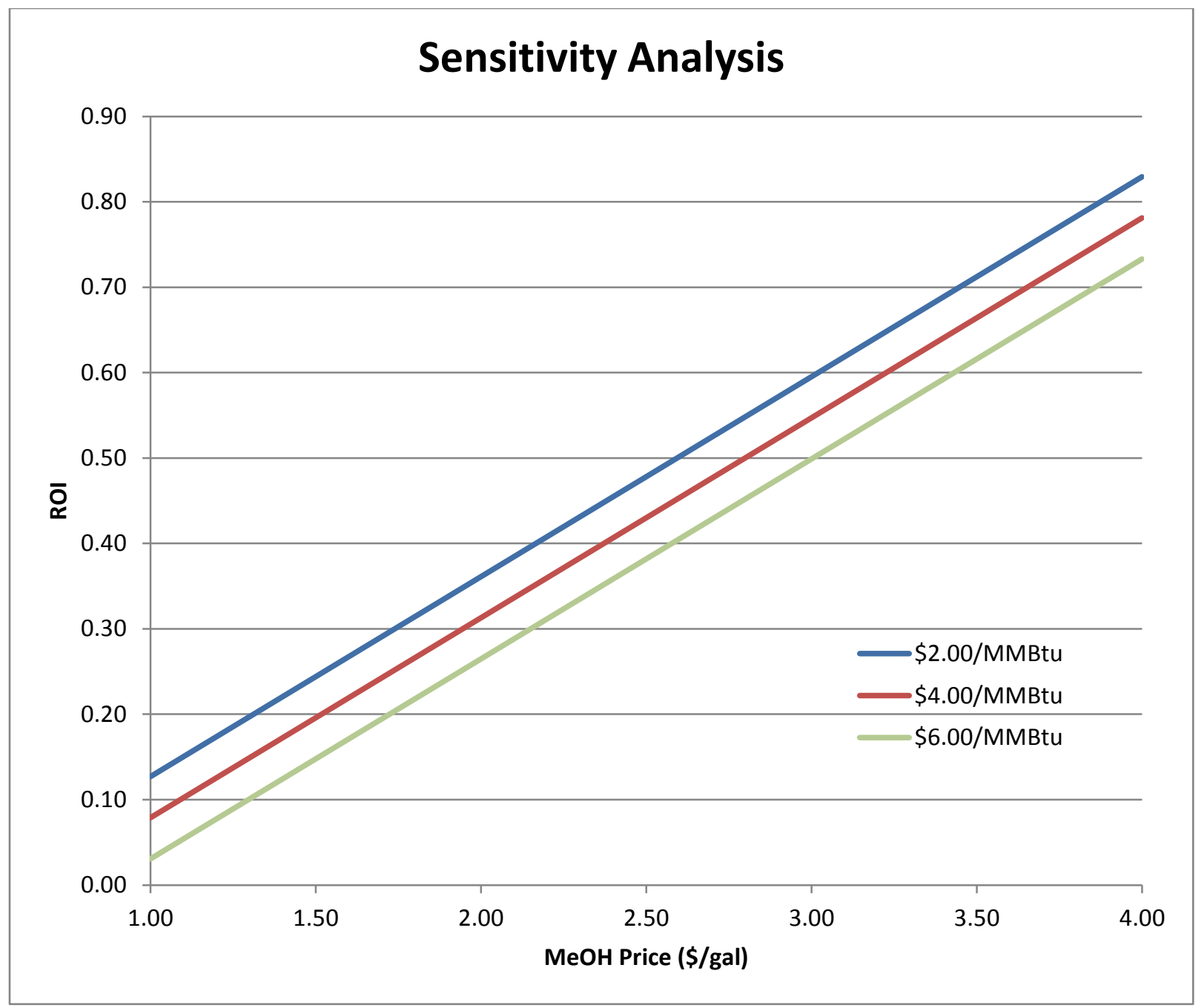

Figure 4. Sensitivity Analysis

Analysis of the inlet gas stream was used to estimate the preprocessing cost for shale gas. For each calculation, $100 \%$ removal was assumed. The primary cost factors included were acid gas removal and nitrogen gas removal. Additionally, some of the total cost is offset through separation of the natural gas liquids (NGLs): ethane and propane. The final cost was then used to determine a price differential between shale gas from the wellhead in comparison with pipeline quality natural gas. Results are shown in Table 5 and Table 6. 
Table 5. Preprocessing Cost Estimation

\begin{tabular}{|c|c|c|c|c|c|}
\hline & \multicolumn{2}{|l|}{$\begin{array}{l}\text { Flow } \\
\text { Rate }\end{array}$} & $\begin{array}{l}\text { Unit Cost } \\
\text { (\$) }\end{array}$ & \multicolumn{2}{|c|}{$\begin{array}{l}\$ 10^{\wedge} 6 \\
\text { Annual }\end{array}$} \\
\hline Acid Gas Removal & 23148 & lbmol/hr & 0.37 & /Mscf feed [16] & 25.95 \\
\hline N2 Removal & 23148 & $\mathrm{lbmol} / \mathrm{hr}$ & 1.30 & /Mscf feed [17] & 90.45 \\
\hline C2 Credit & 1874.988 & $\mathrm{lbmol} / \mathrm{hr}$ & 0.22 & /gal [18] & 35.85 \\
\hline C3 Credit & 532.404 & $\mathrm{lbmol} / \mathrm{hr}$ & 0.97 & /gal [19] & 42.92 \\
\hline \multicolumn{5}{|l|}{ Total } & 37.63 \\
\hline
\end{tabular}

Table 6. Shale Gas Price Differential

\begin{tabular}{|l|r|r|}
\multicolumn{1}{c}{} & \multicolumn{1}{l}{$\begin{array}{l}\text { Unit Cost } \\
\text { (\$/kscf) }\end{array}$} & \multicolumn{1}{c|}{ Total Cost (MM\$/y) } \\
\hline Natural Gas & 3.50 & 179.95 \\
Shale Gas & 2.77 & 142.32 \\
\hline$\delta$ & 0.73 & 37.63 \\
\hline
\end{tabular}

\section{Energy Integration}

The operating cost can be reduced through the use of heat integration and cogeneration. The data for the hot and cold streams are given in Table 7.

Table 7. Heat Exchanger Data

\begin{tabular}{|c|c|c|c|}
\hline Heat exchanger & $\begin{array}{c}\text { Supply } \\
\text { Temperature }\left({ }^{\mathbf{}} \mathbf{F}\right)\end{array}$ & $\begin{array}{c}\text { Target } \\
\text { Temperature }\left({ }^{\mathbf{O}} \mathbf{F}\right)\end{array}$ & $\begin{array}{c}\text { Heat Duty } \\
(\mathbf{M M B t u} / \mathbf{h r})\end{array}$ \\
\hline O2-Heat & 79 & 392 & 25.98 \\
\hline WGS-Heat & 104 & 572 & 153.98 \\
\hline Heat-Rec & 2319 & 104 & 966.30 \\
\hline Cool & 614 & 104 & 174.04 \\
\hline MeOH Cool & 464 & 302 & 144.63 \\
\hline Recycle Cool 1 & 296 & 140 & 113.42 \\
\hline Recycle Cool 2 & 140 & 113 & 13.14 \\
\hline
\end{tabular}

The O2-Heat exchanger takes the inlet flow of oxygen gas and heats it to $200^{\circ} \mathrm{C}$ before entering the POX reactor. The Heat-Rec exchanger cools the syngas mixture from the POX reactor down to $40^{\circ} \mathrm{C}$ and compresses the mixture to 39.5 bar. Condensed liquids are separated from the gas 
stream in the flash column and then the gas stream is heated again in the WGS-Heat exchanger to $300^{\circ} \mathrm{C}$ before entering the WGS reactor. The products from this reactor are then sent to the Cool exchanger where they are again cooled to $40^{\circ} \mathrm{C}$. Unit $\mathrm{MeOH}$ Cool takes the products from the methanol reactor and cools them down to $150^{\circ} \mathrm{C}$ and expands them to 81 bar. Units Recycle Cool 1 and Recycle Cool 2 continue to step down the temperature and pressure to $60^{\circ} \mathrm{C}$ and 77.3 bar, then $45^{\circ} \mathrm{C}$ and 75.6 bar before the crude methanol product is separated from the recycle stream in a final flash column.

By carrying out heat integration through thermal pinch analysis, the targets for minimum heating and cooling utilities are reduced to 0 and 1,649.83 MM Btu/hr. The cooling utility can be further reduced and electric power can be produced using cogeneration. Excess heat is extracted from the hot streams to produce steam which is let down through turbines. Using combined heat and power targeting, the cooling utility is reduced to $620 \mathrm{MMBtu} / \mathrm{hr}$ and the cogenerated electric power is $90.54 \mathrm{MW}$ [20]. Since the total power demand of the process is $14.55 \mathrm{MW}$, then the net power generation of the process is $75.99 \mathrm{MW}$. This corresponds to an annual value of $\$ 30.1$ MM/yr. The following sensitivity analysis shown in Figure 5, which accounts for the savings due to energy integration, shows a corresponding increase in ROI of approximately 2.0 percentage points. Detailed Calculations for the Energy Integration Analysis can be found in Appendix D. 


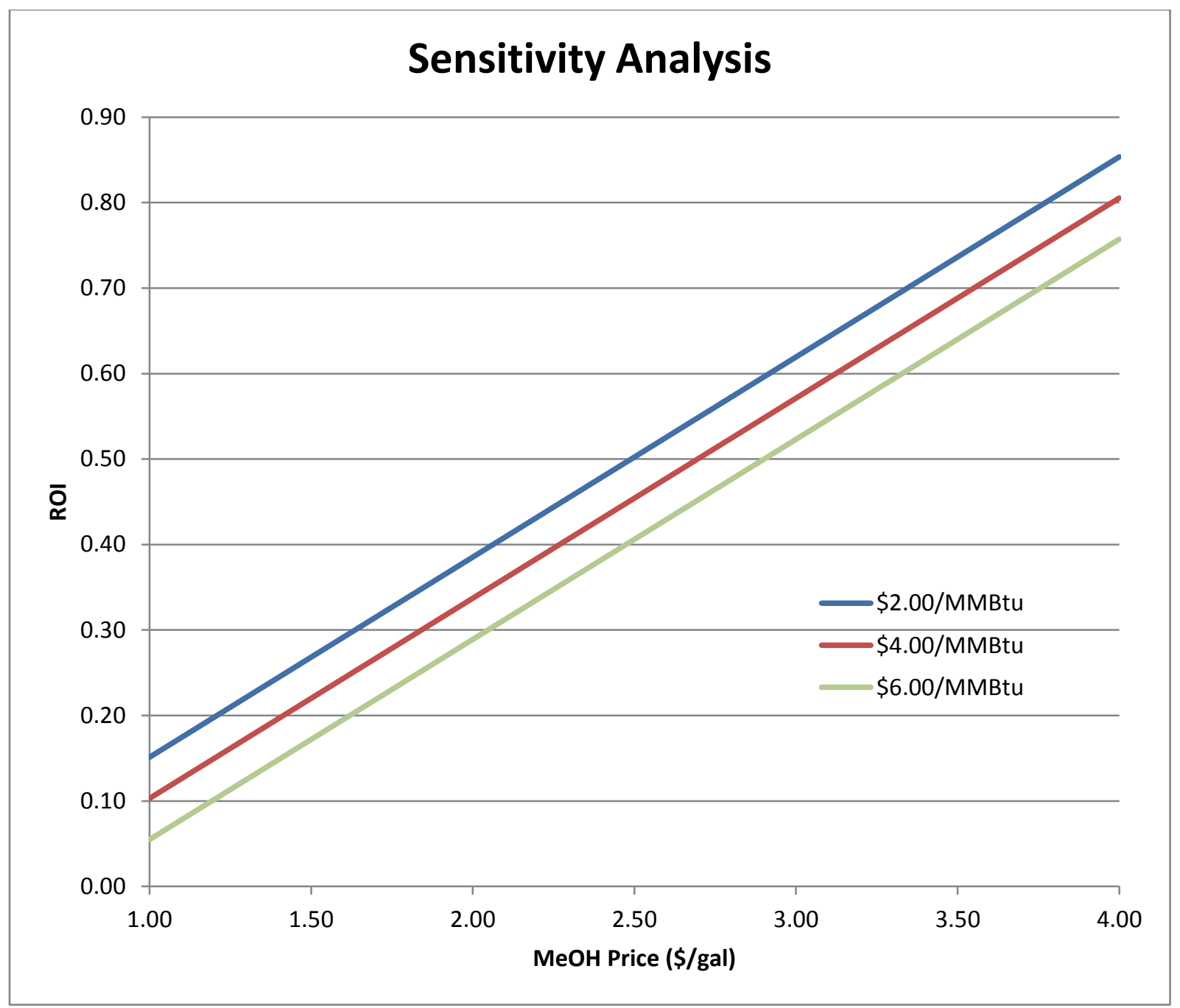

Figure 5. Sensitivity Analysis after Energy Integration

\section{Environmental}

Water is an important resource in multiple aspects of shale gas production, including drilling mud and hydraulic fracturing fluid. Approximately 2-4 million gallons of water are required per well for hydraulic fracturing [21]. This water is typically acquired from sources such as groundwater, surface water, flowback/produced water reuses, treated municipal wastewater, and 
acid mine drainage, with groundwater being the most typical as it is generally available close to production wells [3].

As hydraulic fracturing technology has developed over the previous decade, the demand for water resources in shale gas production has increased. Consequently, water conservation efforts have also increased due competing interests of energy production with agricultural and health needs. Although water use for shale gas production is relatively minor $(<1 \%)$ when compared to irrigation (56\%) and municipal (26\%) water use in Texas, it presents a greater strain in small areas with limited water resources [22]. Additionally, municipal water use is projected to stay relatively constant while shale gas water is projected to increase greatly over the next $30-40$ years [22]. Some limits are already in place due to over abstraction of groundwater in the past for irrigation limits, and many other water conservation methods are being developed for shale gas production [22]. For instance, water from drilling mud, flowback, and produced water can be reused using purification techniques such as filtration, chemical precipitation, reverse osmosis, and evaporation/distillation. Additional benefits of recycling include reducing costs of water acquisition and flowback treatment and disposal. However, the benefits of this approach are limited as recycling and reuse depend on the amount of injected water, and the amount that returns to the surface is only a fraction of the initial amount, about 30\%-70\% [21]. Current researchers are exploring the possibility of replacing fracturing fluid with gases such as propane, nitrogen or carbon dioxide. Additionally, some operators have started exploring brackish groundwater, however this option involves risk of contamination during transport and increased potential of well corrosion [22]. 
Although natural gas burns much cleaner than other fossil fuels, it has been debated whether methane emissions during natural gas production and transportation amount to greater total greenhouse gas emissions. Upstream sources of fugitive emissions are relatively small (2.8\%) compared to emissions from the power station, pipeline, and common elements [21]. In one study performed by Burnham and Han, results show that shale gas life cycle emissions statistically indistinguishable from conventional natural gas, 23\% lower than gasoline, and 33\% lower than coal [23]. Another study performed by Stephenson, Valle, and Riera-Palou found that unconventional gas emissions are about 1.8-2.4\% higher than conventional gas base case, agreeing with the results from Burnham and Han [21]. 


\section{CHAPTER IV}

\section{CONCLUSIONS}

The results of the simulation and cost estimation demonstrate that production of methanol from shale gas would be profitable and a desirable business investment above a methanol selling price of approximately $\$ 1.50 / \mathrm{gal}$. This corresponds with an ROI of at least $20 \%$ or a payback period shorter than five years. The sensitivity analysis shows that the process operating cost depend primarily on the raw natural gas feedstock. However, the ROI depends much more heavily on the selling price of methanol than on the operating costs. Energy Integration accounts for a cost savings of $\$ 30.1$ million per year and corresponds to an increase in ROI of approximately $2 \%$ points. The choice of partial oxidation for synthesis gas generation adds an addition cost for oxygen as a raw material, but some of this cost can be offset through energy integration.

Further analysis led to a cost estimation for the preprocessing of shale gas required to reach pipeline standards, which is necessary for delivery of the raw material to the proposed plant site. Because shale gas can have a chemical composition much different than natural gas, these preprocessing costs may lead to a price differential between shale gas and conventional gas. In the scenario analyzed, the preprocessing costs were dominated by nitrogen removal, with some of the costs being offset from the sale of natural gas liquids (C2 and C3). However, these preprocessing costs require that the shale gas from the wellhead be sold at a lower price than pipeline-quality natural gas. This case shows a clear price differential at $\$ 0.73 / \mathrm{MMBtu}$, but other sources of shale gas with fewer impurities would have a narrower price differential. 
For an environmental prospective, the greenhouse gas emissions for shale gas preprocessing are statistically indistinguishable from those for conventional natural gas. In comparison to other sources of fossil fuels such as petroleum and coal, natural gas has much lower emissions; therefore, shale gas as a raw feedstock provides the same benefit of helping to reduce carbon emissions. Additionally, drilling for shale gas requires water intensive techniques including hydraulic fracturing. This water usage presents some concerns in domestic and semi-arid regions where availability of fresh water is more restricted. Water conservation techniques can be used to reduce water usage and environmental regulation may set limits on water usage in the future, as has been done with water for irrigation. 


\section{REFERENCES}

1. Nash, K.M., Shale gas development. Energy science, engineering and technology. 2010, New York: Nova Science Publishers. ix, 174 p.

2. Häring, H.-W., Industrial gases processing. 2008, Weinheim: Wiley-VCH Verlag GmbH \& Co. KGaA. xiv, 296 p.

3. Gray, J., Marcellus Shale Gas Wastewater Reuse And Recyle, in AIChE/A\&WMA Joint Workshop2012: Pittsburgh, PA. p. 31.

4. Kohl, A.L. and R. Nielsen, Gas purification. 5th ed. 1997, Houston, Tex.: Gulf Pub. viii, $1395 \mathrm{p}$.

5. Goellner, J.F., Expanding the Shale Gas Infrastructure. Chemical Engineering Progress, 2012. 108(8): p. 49-+.

6. Cheng, W.-H. and H.H. Kung, Methanol Production and Use. Chemical Industries. 1994: Marcel Dekker.

7. Bao, B., M.M. El-Halwagi, and N.O. Elbashir, Simulation, integration, and economic analysis of gas-to-liquid processes. Fuel Processing Technology, 2010. 91(7): p. 703713.

8. $\quad$ Noureldin, M.M.B., et al. Process design and integration of XTL plants. in ACS National Meeting. 2012. San Diego.

9. El-Halwagi, M.M., Sustainable design through process integration : fundamentals and applications to industrial pollution prevention, resource conservation, and profitability enhancement. 2012, Amsterdam ; Boston: Butterworth-Heinemann. xi, 422 p.

10. Peters, M.S., K.D. Timmerhaus, and R.E. West, Plant design and economics for chemical engineers. 5th ed. McGraw-Hill chemical engineering series. 2003, New York: McGrawHill. xvii, 988 p.

11. cited 2013; Available from: www.icis.com.

12. Bullin, K. and P. Krouskop, Composition variety complicates processing plans for US Shale Gas, 2008, Bryan Research and Engineering Inc.: Bryan, Texas.

13. Sider, A. Louisiana group plans to build largest methanol plant in North America. Hydrocarbon Processing, 2013. 92(3).

14. Administration, U.S.E.I., Natural Gas Weekly Update, 2013.

15. Bowers, A. and W.W. Eckenfelder, Industrial Wastewater and Best Available Treatment Technologies. 2003: DEStech Publications, Inc.

16. Bhide, B.D., A. Voskericyan, and S.A. Stern, Hybrid processes for the removal of acid gases from natural gas. Journal of Membrane Science, 1998. 140(1): p. 27-49.

17. Lokhandwala, K.A., et al., Nitrogen Removal From Natural Gas Using Membranes, U.S.D.o. Energy, Editor.

18. Clark, B. US spot ethane prices set all-time low on cracker outages, supply. 2013.

19. Weekly Heating Oil and Propane Prices (October-March). 2013; Available from: http://www.eia.gov/dnav/pet/pet_pri_wfr_dcus_nus_w.htm.

20. El-Halwagi, M.M., D. Harell, and H.D. Spriggs, Targeting Cogeneration and Waste Utilization through Process Integration. Applied Energy, 2009. 86(6): p. 880-887.

21. Stephenson, T., J.E. Valle, and X. Riera-Palou, Modeling the Relative GHG Emissions of Conventional and Shale Gas Production. Environmental Science \& Technology, 2011. 45(24): p. 10757-10764. 
22. Nicot, J.P. and B.R. Scanlon, Water Use for Shale-Gas Production in Texas, US.

Environmental Science \& Technology, 2012. 46(6): p. 3580-3586.

23. Burnham, A., et al., Life-Cycle Greenhouse Gas Emissions of Shale Gas, Natural Gas, Coal, and Petroleum (vol 46, pg 619, 2012). Environmental Science \& Technology, 2012. 46(13): p. 7430-7430.

24. Tranier, J.P., N. Perrin, and R. Dubettier, Air separation units for cola power plants. Carbon Capture Journal, 2011(June). 


\section{APPENDIX A}

\section{PROCESS FLOW DIAGRAMS}

\section{Overall Process}

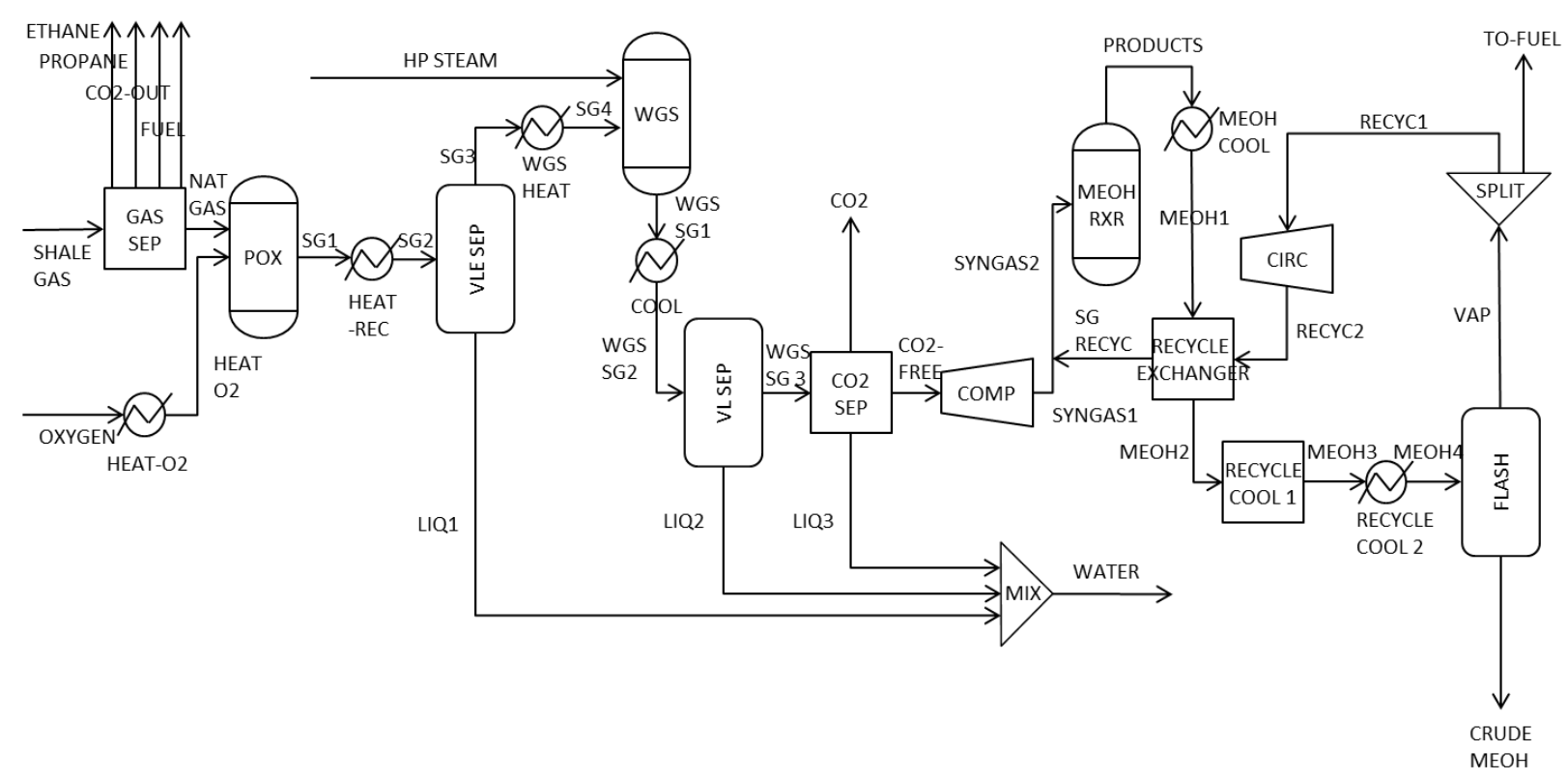

First oxygen gas is heated to $200^{\circ} \mathrm{C}$. The heated oxygen and natural gas are fed to the POX reactor where the raw materials react at 20 bar in order to form hydrogen gas and carbon monoxide in approximately a 1.8:1 ratio. In the HEAT-REC exchanger the products are cooled to $40^{\circ} \mathrm{C}$ and pressurized to 39.5 bar. In order to adjust the ratio to the stoichiometric value of 2.0, the gas mixture is sent through a flash column and then to the WGS reactor at $300^{\circ} \mathrm{C}$ where a water-gas shift reaction occurs.

$$
\mathrm{CO}+\mathrm{H}_{2} \mathrm{O} \leftrightarrow \mathrm{CO}_{2}+\mathrm{H}_{2} \quad \Delta \mathrm{Hr}=41.1 \mathrm{~kJ} / \mathrm{mol}
$$

Next, the products from the WGS reactor are cooled back down to $40^{\circ} \mathrm{C}$ and sent to a flash column where the liquid water separates from the syngas. The next unit removes carbon dioxide 
from the water-gas shift reaction. Next, the gas is compressed to $75 \mathrm{~atm}$ and sent to the MEOHRXR where it reacts at $240^{\circ} \mathrm{C}$ to form methanol vapor. The products from this reaction are then sent through a recycle loop with heat exchangers and compressors in order to maximize conversion of the feedstock. The crude methanol product is separated from the recycle stream in a flash column. The recycle ratio is set at 0.5 .

\section{Gas Separation}

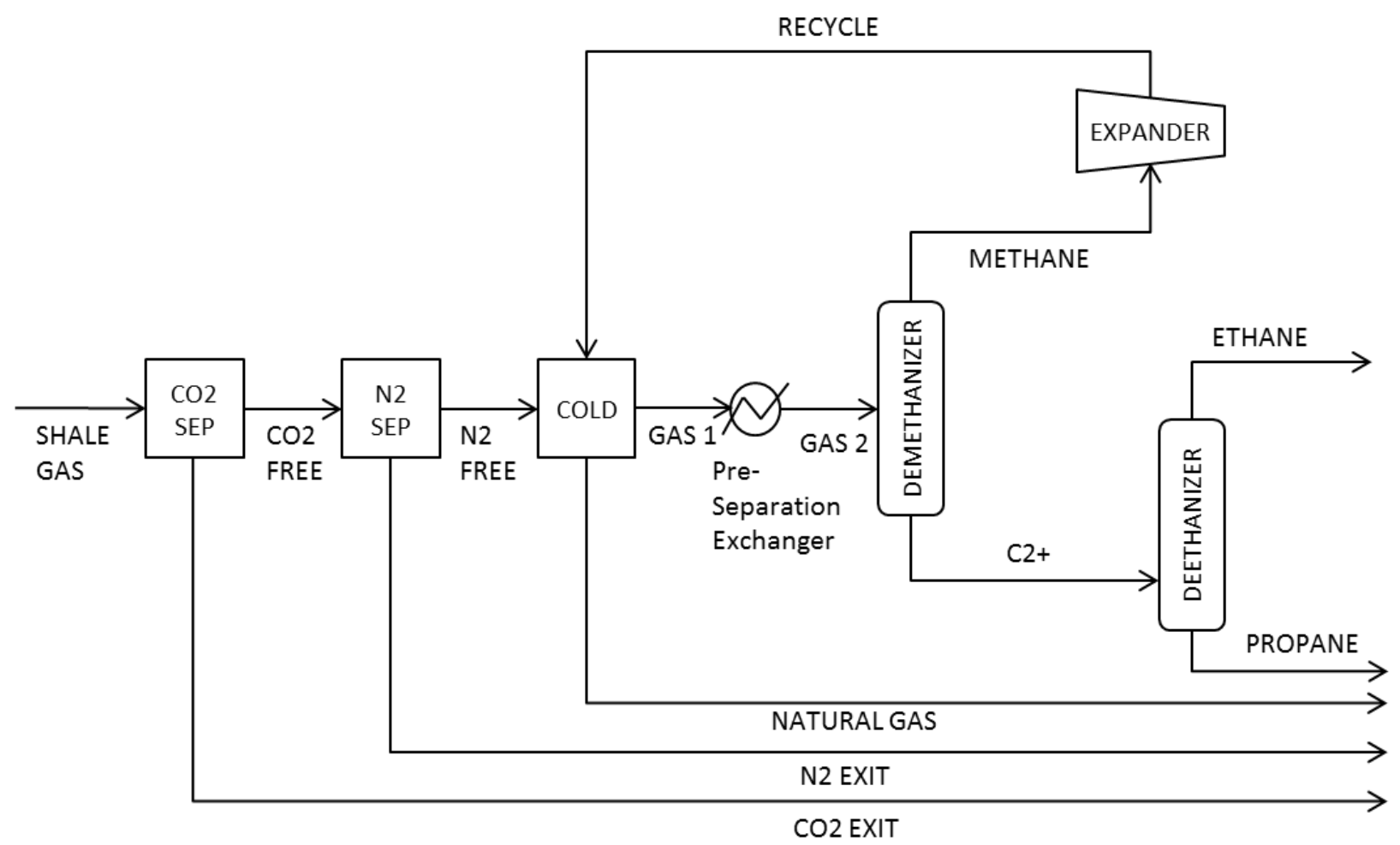

Before the shale gas feedstock can be sent via pipeline to the methanol plant, it must first undergo several preprocessing steps in order to remove contaminants that are limited by pipeline standards. The process diagram above shows that the gas is first sent through a carbon dioxide removal unit and then through a nitrogen gas separation unit (details show in following diagram). Next the gas is sent through a heat exchanger and a series of distillation columns in order to remove the NGLs. The first cryogenic column has 15 stages and removes methane from the 
higher boiling hydrocarbons. In the second cryogenic column, ethane and propane are separated through 23 stages and purified in order to be sold for a profit. Both columns have a molar reflux ratio of 1.5 .

\section{Nitrogen Separation}

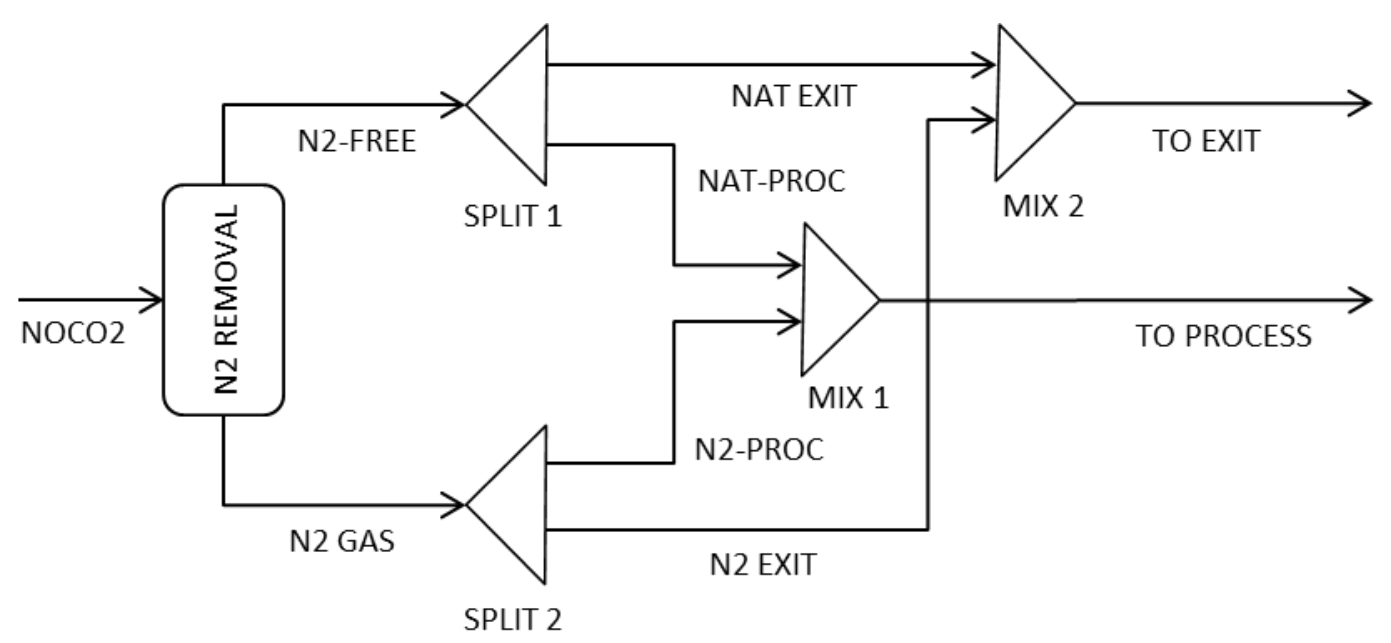

The progress diagram above shows the natural gas inlet stream entering at the left into a separation unit. The gas is then split into a nitrogen-rich and nitrogen-free stream. Each stream goes through another separation step and the nitrogen gas is released to the atmosphere while the process gas is sent to a heat exchanger before it enters the demethanizer and deethanizer columns. 


\section{APPENDIX B}

\section{SIMULATION STREAM DATA}

\begin{tabular}{|c|c|c|c|c|c|c|}
\hline \multirow[b]{2}{*}{ Mole Flow $\mathrm{lbmol} / \mathrm{hr}$} & $\mathrm{CO} 2$ & CO2-FREE & CO2-OUT & \multirow[t]{2}{*}{ CRUDEMEOH } & ETHANE & FUEL \\
\hline & & & & & & \\
\hline $\mathrm{H} 2$ & 0 & 30105.04 & 0 & 3.14E-03 & 0 & 0 \\
\hline WATER & 0 & 94.74258 & 0 & 2.695566 & 0 & 0 \\
\hline $\mathrm{CH} 4$ & 0 & 50.14277 & 0 & 30.59069 & 0.078948 & 1597.942 \\
\hline N2 & 0 & 15.34547 & 0 & 2.113667 & 6.11E-09 & 1813.256 \\
\hline $\mathrm{C} 2 \mathrm{H} 6$ & 0 & $3.65 E-04$ & 0 & $2.74 \mathrm{E}-04$ & 1694.966 & 161.1872 \\
\hline $\mathrm{C} 3 \mathrm{H} 8$ & 0 & $6.51 \mathrm{E}-09$ & 0 & 5.77E-09 & 7.596043 & 45.7692 \\
\hline $\mathrm{CO}$ & 0 & 15052.9 & 0 & 404.0464 & 0 & 0 \\
\hline METHANOL & 0 & 0 & 0 & 12523.65 & 0 & 0 \\
\hline BUTANOL & 0 & 0 & 0 & 1.762827 & 0 & 0 \\
\hline $\mathrm{C} 2 \mathrm{H} 6 \mathrm{O}-01$ & 0 & 0 & 0 & 0.367579 & 0 & 0 \\
\hline ACETONE & 0 & 0 & 0 & 0.6523228 & 0 & 0 \\
\hline $\mathrm{O} 2$ & 0 & $5.91 \mathrm{E}-10$ & 0 & 1.73E-10 & 0 & 0 \\
\hline $\mathrm{CO} 2$ & 226.8504 & 2.680371 & 1737.82 & 55.11302 & 2.836543 & 8.357854 \\
\hline Total Flow lbmol/hr & 226.8504 & 45320.86 & 1737.82 & 13020.99 & 1705.478 & 3626.513 \\
\hline Total Flow $\mathrm{lb} / \mathrm{hr}$ & 9983.641 & $4.85 \mathrm{E}+05$ & 76481.11 & $4.16 \mathrm{E}+05$ & 51428.08 & 83663.95 \\
\hline Total Flow cuft/hr & 2270.854 & $4.87 E+05$ & 14864.06 & 8820.684 & 15651.81 & 41956.35 \\
\hline Temperature F & 100 & 104 & 104 & 113 & 40.79148 & 98.31344 \\
\hline Pressure psia & 500 & 572.8991 & 572.8991 & 1096.485 & 389.6959 & 500 \\
\hline Vapor Frac & 1 & 1 & 1 & 0 & 1 & 1 \\
\hline Liquid Frac & 0 & 0 & 0 & 1 & 0 & 0 \\
\hline Solid Frac & 0 & 0 & 0 & 0 & 0 & 0 \\
\hline Enthalpy Btu/lbmol & $-1.70 E+05$ & -15865.61 & $-1.70 E+05$ & $-1.00 E+05$ & -37764.75 & -16671.43 \\
\hline Enthalpy Btu/lb & -3852.03 & -1481.387 & -3853.185 & -3137.149 & -1252.369 & -722.643 \\
\hline Enthalpy Btu/hr & $-3.85 \mathrm{E}+07$ & $-7.19 \mathrm{E}+08$ & $-2.95 \mathrm{E}+08$ & $-1.30 E+09$ & $-6.44 E+07$ & $-6.05 E+07$ \\
\hline Entropy Btu/lbmol-R & -6.617316 & 1.373276 & -6.929996 & -53.67263 & -50.37662 & -16.24108 \\
\hline Entropy Btu/lb-R & -0.1503601 & 0.128224 & -0.1574648 & -1.680739 & -1.670609 & -0.7039888 \\
\hline Density Ibmol/cuft & 0.0998965 & 0.09308 & 0.1169142 & 1.476188 & 0.1089636 & 0.0864353 \\
\hline Density $\mathrm{lb} /$ cuft & 4.396426 & 0.9968849 & 5.14537 & 47.14053 & 3.28576 & 1.994071 \\
\hline Average MW & 44.0098 & 10.70997 & 44.0098 & 31.93395 & 30.15465 & 23.07008 \\
\hline Liq Vol 60F cuft/hr & 194.6181 & 38827.49 & 1490.9 & 8518.03 & 2313.088 & 3216.297 \\
\hline
\end{tabular}


Mole Flow Ibmol/hr

$\mathrm{H} 2$

WATER

$\mathrm{CH} 4$

$\mathrm{N} 2$

$\mathrm{C} 2 \mathrm{H} 6$

$\mathrm{C} 3 \mathrm{H} 8$

$\mathrm{CO}$

METHANOL

BUTANOL

C2H6O-01

ACETONE

$\mathrm{O} 2$

$\mathrm{CO} 2$

Total Flow $\mathrm{lbmol} / \mathrm{hr}$

Total Flow $\mathrm{lb} / \mathrm{hr}$

Total Flow cuft/hr

Temperature $\mathrm{F}$

Pressure psia

Vapor Frac

Liquid Frac

Solid Frac

Enthalpy Btu/lbmol

Enthalpy Btu/lb

Enthalpy Btu/hr

Entropy Btu/lbmol-R

Entropy Btu/lb-R

Density Ibmol/cuft

Density lb/cuft

Average MW

Liq Vol 60F cuft/hr

\section{HEATO2 HP-STEAM}

LIQ1

LIQ2

LIQ3

\begin{tabular}{|c|c|c|c|c|}
\hline 0 & 0 & 5.00E-04 & 5.49E-06 & $3.41 \mathrm{E}-06$ \\
\hline 0 & 983.1172 & 4658.411 & 50.12463 & 22.50542 \\
\hline 0 & 0 & 2.758614 & 0.0293126 & 0.017671 \\
\hline 0 & 0 & 0.0892899 & $9.50 \mathrm{E}-04$ & 5.79E-04 \\
\hline 0 & 0 & $4.28 \mathrm{E}-05$ & 4.54E-07 & $2.65 \mathrm{E}-07$ \\
\hline 0 & 0 & $1.98 \mathrm{E}-09$ & $2.10 \mathrm{E}-11$ & $1.25 \mathrm{E}-11$ \\
\hline 0 & 0 & 120.4079 & 1.205964 & 0.732065 \\
\hline 0 & 0 & 0 & 0 & c \\
\hline 0 & 0 & 0 & 0 & c \\
\hline 0 & 0 & 0 & 0 & c \\
\hline 0 & 0 & 0 & 0 & c \\
\hline 11294 & 0 & 8.87E-12 & $9.43 \mathrm{E}-14$ & c \\
\hline 0 & 0 & 139.0785 & 3.107723 & $2.98 \mathrm{E}-03$ \\
\hline 11294 & 983.1172 & 4920.746 & 54.46859 & 23.25872 \\
\hline $3.61 E+05$ & 17711.13 & 93462.82 & 1074.056 & 426.3779 \\
\hline $2.74 \mathrm{E}+05$ & 15196.14 & 1537.793 & 17.45731 & 7.135988 \\
\hline 392 & 481.4268 & 104 & 104 & 104 \\
\hline 377.0981 & 572.8991 & 572.8991 & 572.8991 & 794.6365 \\
\hline 1 & 1 & 0 & 0 & c \\
\hline 0 & 0 & 1 & 1 & 1 \\
\hline 0 & 0 & 0 & 0 & c \\
\hline 2225.072 & $-1.01 E+05$ & $-1.23 E+05$ & $-1.25 E+05$ & $-1.20 \mathrm{E}+05$ \\
\hline 69.53609 & -5621.948 & -6456.023 & -6331.834 & -6548.123 \\
\hline $2.51 \mathrm{E}+07$ & $-9.96 E+07$ & $-6.03 E+08$ & $-6.80 E+06$ & $-2.79 E+0 €$ \\
\hline-3.181569 & -13.71614 & -36.97206 & -37.24206 & -36.49904 \\
\hline 0.0994277 & 0.7613615 & -1.94655 & -1.888656 & $-1.99100 €$ \\
\hline 0.0411957 & 0.0646951 & 3.199875 & 3.120103 & 3.259356 \\
\hline 1.318213 & 1.165502 & 60.77723 & 61.52473 & 59.75038 \\
\hline 31.9988 & 18.01528 & 18.99363 & 19.71881 & 18.33196 \\
\hline 9689.274 & 284.2519 & 1571.962 & 18.21944 & 7.153334 \\
\hline
\end{tabular}




\begin{tabular}{|c|c|c|c|c|c|c|}
\hline & MEOH1 & MEOH2 & MEOH3 & MEOH4 & NAT-GAS & OXYGEN \\
\hline \multicolumn{7}{|l|}{ Mole Flow $\mathrm{lbmol} / \mathrm{hr}$} \\
\hline $\mathrm{H} 2$ & 10010.28 & 10010.28 & 10010.28 & 10010.28 & 0 & 0 \\
\hline WATER & 2.703435 & 2.703435 & 2.703435 & 2.703435 & 0 & 0 \\
\hline $\mathrm{CH} 4$ & 69.65949 & 69.65949 & 69.65949 & 69.65949 & 16989.82 & 0 \\
\hline N2 & 28.57612 & 28.57612 & 28.57612 & 28.57612 & 15.43571 & 0 \\
\hline $\mathrm{C} 2 \mathrm{H} 6$ & 4.55E-04 & $4.55 \mathrm{E}-04$ & 4.55E-04 & $4.55 \mathrm{E}-04$ & 17.13801 & 0 \\
\hline $\mathrm{C} 3 \mathrm{H} 8$ & $7.23 \mathrm{E}-09$ & $7.23 E-09$ & $7.23 \mathrm{E}-09$ & 7.23E-09 & $2.03 \mathrm{E}-03$ & 0 \\
\hline $\mathrm{CO}$ & 4369.74 & 4369.74 & 4369.74 & 4369.74 & 0 & 0 \\
\hline METHANOL & 12633.69 & 12633.69 & 12633.69 & 12633.69 & 0 & 0 \\
\hline BUTANOL & 1.764569 & 1.764569 & 1.764569 & 1.764569 & 0 & 0 \\
\hline $\mathrm{C} 2 \mathrm{H} 6 \mathrm{O}-01$ & 0.5142695 & 0.5142695 & 0.5142695 & 0.5142695 & 0 & 0 \\
\hline ACETONE & 0.6704506 & 0.6704506 & 0.6704506 & 0.6704506 & 0 & 0 \\
\hline $\mathrm{O} 2$ & $1.01 \mathrm{E}-09$ & $1.01 \mathrm{E}-09$ & $1.01 \mathrm{E}-09$ & $1.01 \mathrm{E}-09$ & 0 & 11294 \\
\hline $\mathrm{CO} 2$ & 103.4267 & 103.4267 & 103.4267 & 103.4267 & 86.0272 & 0 \\
\hline Total Flow lbmol/hr & 27221.03 & 27221.03 & 27221.03 & 27221.03 & 17108.43 & 11294 \\
\hline Total Flow $\mathrm{lb} / \mathrm{hr}$ & $5.54 \mathrm{E}+05$ & $5.54 \mathrm{E}+05$ & $5.54 \mathrm{E}+05$ & $5.54 \mathrm{E}+05$ & 2.77E+05 & $3.61 E+05$ \\
\hline Total Flow cuft/hr & $1.35 \mathrm{E}+05$ & $1.33 \mathrm{E}+05$ & 94392.71 & 91257.57 & $2.51 \mathrm{E}+05$ & $1.70 \mathrm{E}+05$ \\
\hline Temperature F & 302 & 296.3073 & 140 & 113 & 78.8 & 78.8 \\
\hline Pressure psia & 1174.806 & 1174.806 & 1121.142 & 1096.485 & 377.0981 & 377.0981 \\
\hline Vapor Frac & 0.6806229 & 0.6665614 & 0.5286863 & 0.5216568 & 1 & 1 \\
\hline Liquid Frac & 0.3193771 & 0.3334386 & 0.4713137 & 0.4783432 & 0 & 0 \\
\hline Solid Frac & 0 & 0 & 0 & 0 & 0 & 0 \\
\hline Enthalpy Btu/lbmol & -50513.42 & -50762.57 & -54929.36 & -55412.01 & -32873.68 & -74.94573 \\
\hline Enthalpy Btu/lb & -2481.549 & -2493.789 & -2698.489 & -2722.199 & -2028.208 & -2.342142 \\
\hline Enthalpy Btu/hr & $-1.38 \mathrm{E}+09$ & $-1.38 \mathrm{E}+09$ & $-1.50 \mathrm{E}+09$ & $-1.51 E+09$ & $-5.62 E+08$ & $-8.46 E+05$ \\
\hline Entropy Btu/lbmol-R & -19.30193 & -19.62616 & -25.50496 & -26.27779 & -25.73844 & -6.546079 \\
\hline Entropy $\quad B t u / l b-R$ & 0.9482367 & 0.9641652 & -1.25297 & -1.290936 & -1.587985 & 0.2045726 \\
\hline Density Ibmol/cuft & 0.2011598 & 0.2054419 & 0.2883806 & 0.2982879 & 0.0681314 & 0.0664557 \\
\hline Density lb/cuft & 4.094728 & 4.181893 & 5.87016 & 6.071829 & 1.10429 & 2.126505 \\
\hline Average MW & 20.3556 & 20.3556 & 20.3556 & 20.3556 & 16.20824 & 31.9988 \\
\hline Liq Vol 60F cuft/hr & 20677.17 & 20677.17 & 20677.17 & 20677.17 & 14686.11 & 9689.274 \\
\hline
\end{tabular}




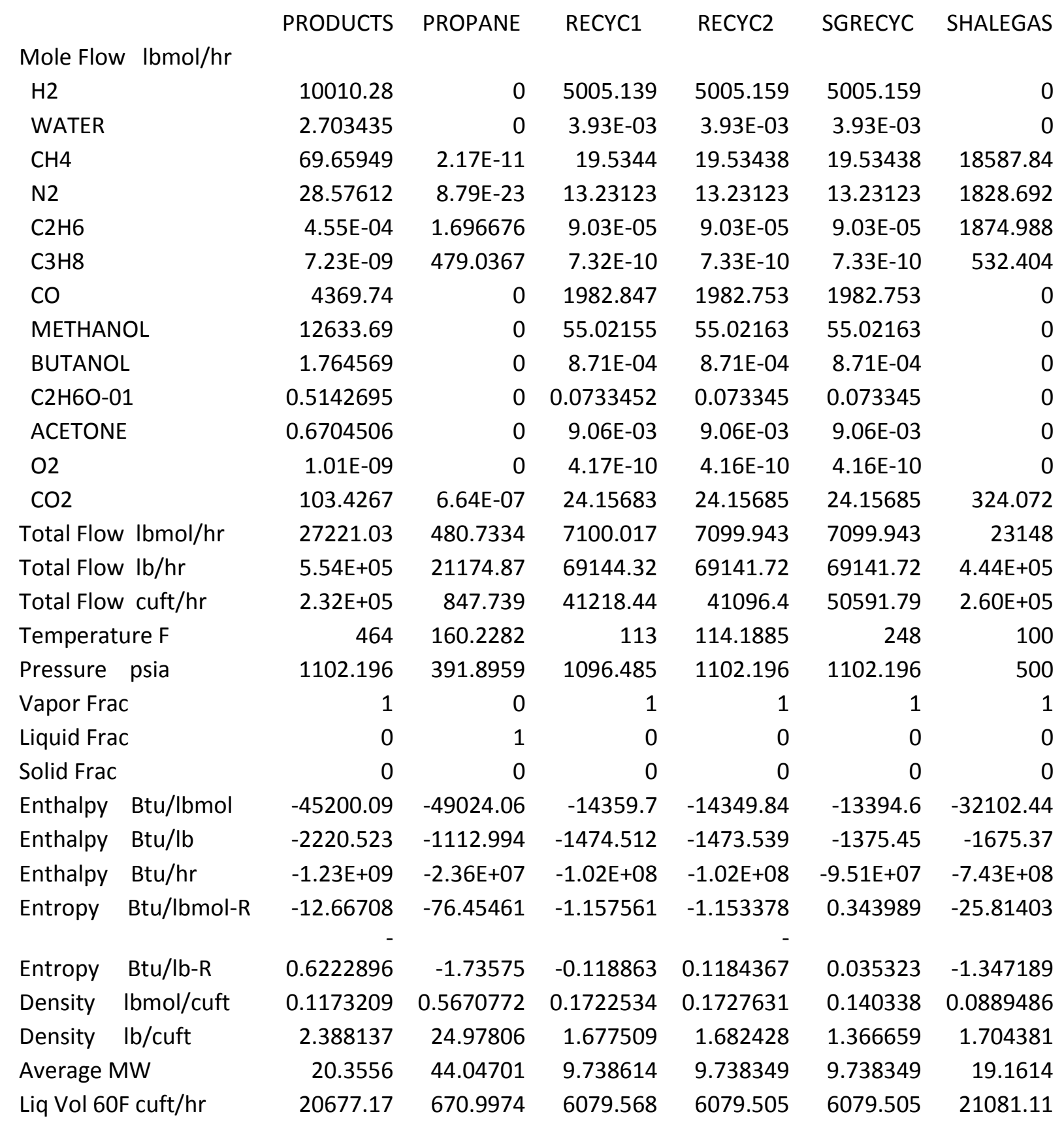




\begin{tabular}{|c|c|c|c|c|c|c|}
\hline & SG1 & SG2 & SG3 & SG4 & SYNGAS1 & SYNGAS2 \\
\hline \multicolumn{7}{|l|}{ Aole Flow Ibmol/hr } \\
\hline $\mathrm{H} 2$ & 29171.35 & 29171.35 & 29171.35 & 29171.35 & 35110.2 & 30105.04 \\
\hline WATER & 4753.854 & 4753.854 & 95.44336 & 95.44336 & 72.24109 & 72.23716 \\
\hline $\mathrm{CH} 4$ & 52.9307 & 52.9307 & 50.17209 & 50.17209 & 69.65949 & 50.1251 \\
\hline N2 & 15.43571 & 15.43571 & 15.34642 & 15.34642 & 28.57612 & 15.34489 \\
\hline $\mathrm{C} 2 \mathrm{H} 6$ & 4.08E-04 & $4.08 \mathrm{E}-04$ & $3.65 \mathrm{E}-04$ & 3.65E-04 & $4.55 E-04$ & $3.65 E-04$ \\
\hline $\mathrm{C} 3 \mathrm{H} 8$ & 8.51E-09 & 8.51E-09 & $6.53 \mathrm{E}-09$ & $6.53 \mathrm{E}-09$ & $7.23 \mathrm{E}-09$ & $6.50 \mathrm{E}-09$ \\
\hline $\mathrm{CO}$ & 16108.21 & 16108.21 & 15987.8 & 15987.8 & 17034.92 & 15052.17 \\
\hline METHANOL & 0 & 0 & 0 & 0 & 55.02163 & 0 \\
\hline BUTANOL & 0 & 0 & 0 & 0 & 8.71E-04 & 0 \\
\hline $\mathrm{C} 2 \mathrm{H} 6 \mathrm{O}-01$ & 0 & 0 & 0 & 0 & 0.073345 & 0 \\
\hline ACETONE & 0 & 0 & 0 & 0 & $9.06 \mathrm{E}-03$ & 0 \\
\hline $\mathrm{O} 2$ & $6.00 \mathrm{E}-10$ & $6.00 \mathrm{E}-10$ & $5.91 \mathrm{E}-10$ & $5.91 \mathrm{E}-10$ & $1.01 \mathrm{E}-09$ & $5.91 \mathrm{E}-10$ \\
\hline $\mathrm{CO} 2$ & 948.9932 & 948.9932 & 809.9148 & 809.9148 & 26.83424 & 2.677387 \\
\hline Total Flow Ibmc & 51050.77 & 51050.77 & 46130.03 & 46130.03 & 52397.54 & 45297.6 \\
\hline Total Flow $\mathrm{lb} / \mathrm{hr}$ & $6.39 \mathrm{E}+05$ & $6.39 \mathrm{E}+05$ & $5.45 \mathrm{E}+05$ & $5.45 \mathrm{E}+05$ & $5.54 \mathrm{E}+05$ & $4.85 \mathrm{E}+05$ \\
\hline Total Flow cuft/hr & $4.21 \mathrm{E}+06$ & $4.96 \mathrm{E}+05$ & $4.95 \mathrm{E}+05$ & $9.04 \mathrm{E}+05$ & $3.08 \mathrm{E}+05$ & $2.57 \mathrm{E}+05$ \\
\hline Temperature F & 2319.394 & 104 & 104 & 572 & 122.7678 & 104 \\
\hline Pressure psia & 362.5943 & 572.8991 & 572.8991 & 572.8991 & 1102.196 & 1102.196 \\
\hline Vapor Frac & 1 & 0.9036108 & 1 & 1 & 1 & 0.9996128 \\
\hline Liquid Frac & 0 & 0.0963892 & 0 & 0 & 0 & 3.87E-04 \\
\hline Solid Frac & 0 & 0 & 0 & 0 & 0 & 0 \\
\hline Enthalpy Btu/lbmol & -10524.56 & -29452.83 & -19514.23 & -16176.22 & -15499.86 & -15829.84 \\
\hline Enthalpy Btu/lb & -841.2304 & -2354.171 & -1651.034 & -1368.616 & -1465.717 & -1478.588 \\
\hline Enthalpy Btu/hr & $-5.37 E+08$ & $-1.50 E+09$ & $-9.00 \mathrm{E}+08$ & $-7.46 \mathrm{E}+08$ & $-8.12 E+08$ & $-7.17 E+08$ \\
\hline Entropy Btu/lbmol-R & 13.72227 & -1.877333 & 1.866263 & 6.174613 & 0.1023631 & 0.0285566 \\
\hline Entropy Btu/lb-R & 1.096824 & 0.1500556 & 0.1578983 & 0.5224136 & $9.68 \mathrm{E}-03$ & $2.67 \mathrm{E}-03$ \\
\hline Density Ibmol/cuft & 0.012112 & 0.1028673 & 0.0932409 & 0.0510302 & 0.1702405 & 0.175956 \\
\hline Density $\mathrm{lb} /$ cuft & 0.1515331 & 1.286964 & 1.102052 & 0.6031468 & 1.800281 & 1.883795 \\
\hline Average MW & 12.51091 & 12.51091 & 11.8194 & 11.8194 & 10.57493 & 10.70606 \\
\hline Liq Vol 60F cuft/hr & 41093.26 & 41093.26 & 39521.29 & 39521.29 & 44899.85 & 38820.34 \\
\hline
\end{tabular}




\begin{tabular}{|c|c|c|c|c|c|c|}
\hline & TO-FUEL & WGS SG3 & WGS SG1 & WGS SG2 & WATER & VAP \\
\hline \multicolumn{7}{|l|}{ Mole Flow $\mathrm{lbmol} / \mathrm{hr}$} \\
\hline $\mathrm{H} 2$ & 5005.139 & 30105.04 & 30105.04 & 30105.04 & 5.09E-04 & 10010.28 \\
\hline WATER & 3.93E-03 & 94.74258 & 144.8672 & 144.8672 & 4731.041 & 7.87E-03 \\
\hline $\mathrm{CH} 4$ & 19.5344 & 50.14277 & 50.17209 & 50.17209 & 2.805598 & 39.06879 \\
\hline N2 & 13.23123 & 15.34547 & 15.34642 & 15.34642 & 0.0908186 & 26.46245 \\
\hline $\mathrm{C} 2 \mathrm{H} 6$ & $9.03 E-05$ & $3.65 E-04$ & $3.65 \mathrm{E}-04$ & $3.65 \mathrm{E}-04$ & $4.36 \mathrm{E}-05$ & $1.81 \mathrm{E}-04$ \\
\hline $\mathrm{C} 3 \mathrm{H} 8$ & $7.32 \mathrm{E}-10$ & $6.51 \mathrm{E}-09$ & $6.53 \mathrm{E}-09$ & $6.53 \mathrm{E}-09$ & $2.02 \mathrm{E}-09$ & 1.46E-09 \\
\hline $\mathrm{CO}$ & 1982.847 & 15052.9 & 15054.11 & 15054.11 & 122.3459 & 3965.694 \\
\hline METHANOL & 55.02155 & 0 & 0 & 0 & 0 & 110.0431 \\
\hline BUTANOL & $8.71 E-04$ & 0 & 0 & 0 & 0 & $1.74 \mathrm{E}-03$ \\
\hline $\mathrm{C} 2 \mathrm{H} 6 \mathrm{O}-01$ & 0.0733452 & 0 & 0 & 0 & 0 & 0.1466906 \\
\hline ACETONE & $9.06 \mathrm{E}-03$ & 0 & 0 & 0 & 0 & 0.0181278 \\
\hline $\mathrm{O} 2$ & 4.17E-10 & $5.91 \mathrm{E}-10$ & $5.91 \mathrm{E}-10$ & $5.91 \mathrm{E}-10$ & $8.96 \mathrm{E}-12$ & $8.34 \mathrm{E}-10$ \\
\hline $\mathrm{CO} 2$ & 24.15683 & 1740.5 & 1743.608 & 1743.608 & 142.1892 & 48.31366 \\
\hline Total Flow Ibmol/hr & 7100.017 & 47058.68 & 47113.14 & 47113.14 & 4998.473 & 14200.03 \\
\hline Total Flow $\mathrm{lb} / \mathrm{hr}$ & 69144.32 & $5.62 E+05$ & $5.63 \mathrm{E}+05$ & $5.63 E+05$ & 94963.26 & $1.38 \mathrm{E}+05$ \\
\hline Total Flow cuft/hr & 41218.44 & $5.04 \mathrm{E}+05$ & $9.60 \mathrm{E}+05$ & $5.04 \mathrm{E}+05$ & 1562.399 & 82436.88 \\
\hline Temperature F & 113 & 104 & 613.8253 & 104 & 104.0196 & 113 \\
\hline Pressure psia & 1096.485 & 572.8991 & 572.8991 & 572.8991 & 572.8991 & 1096.485 \\
\hline Vapor Frac & 1 & 1 & 1 & 0.9988439 & 0 & 1 \\
\hline Liquid Frac & 0 & 0 & 0 & $1.16 \mathrm{E}-03$ & 1 & 0 \\
\hline Solid Frac & 0 & 0 & 0 & 0 & 0 & 0 \\
\hline Enthalpy Btu/lbmol & -14359.7 & -21526.84 & -17952.2 & -21646.3 & $-1.23 \mathrm{E}+05$ & -14359.7 \\
\hline Enthalpy Btu/lb & -1474.512 & -1802.965 & -1502.441 & -1811.605 & -6455.032 & -1474.512 \\
\hline Enthalpy Btu/hr & $-1.02 E+08$ & $-1.01 E+09$ & $-8.46 \mathrm{E}+08$ & $-1.02 E+09$ & $-6.13 E+08$ & $-2.04 E+08$ \\
\hline Entropy Btu/lbmol-R & -1.157561 & 1.397678 & 6.026266 & 1.353006 & -36.97216 & -1.157561 \\
\hline Entropy Btu/lb-R & -0.118863 & 0.1170615 & 0.5043455 & 0.1132347 & -1.946062 & -0.118863 \\
\hline Density Ibmol/cuft & 0.1722534 & 0.0933167 & 0.0490685 & 0.0934214 & 3.199229 & 0.1722534 \\
\hline Density lb/cuft & 1.677509 & 1.114173 & 0.5863047 & 1.116264 & 60.7804 & 1.677509 \\
\hline Average MW & 9.738614 & 11.93969 & 11.94869 & 11.94869 & 18.99845 & 9.738614 \\
\hline Liq Vol 60F cuft/hr & 6079.568 & 40318.39 & 40336.61 & 40336.61 & 1597.335 & 12159.14 \\
\hline
\end{tabular}




\section{APPENDIX C}

\section{CALCULATIONS}

Abbreviations:

FCI $=$ Fixed Capital Investment

$\mathrm{WCI}=$ Working Capital Investment

TCI $=$ Total Capital Investment

AOC $=$ Annual Operating Cost

AATP $=$ Annual After-Tax Profit

$\mathrm{AFC}=$ Annualized Fixed Cost

ROI $=$ Return on Investment

Capital Cost: $\$ 1.3$ Billion

\section{Operating Costs:}

Raw Materials

$$
\begin{aligned}
& \text { Natural Gas: } C_{N G}=155.8 \frac{M M s c f}{d a y} * 1000 \frac{k s c f}{M M s c f} * \$ 3.50 \frac{1}{k s c f} * 330 \frac{\text { day }}{\text { year }} \\
& \text { Oxygen: } C_{O_{2}}=361394 \frac{l b}{h r} * \$ 0.05 \frac{1}{l b} * 24 \frac{h r}{\text { day }} * 330 \frac{\text { day }}{\text { year }}
\end{aligned}
$$

Utilities

Heating: $C_{\text {Heat }}=1.800 * 10^{8} \frac{B t u}{h r} * \frac{M M B t u}{10^{6} B t u} * \$ 4.00 \frac{1}{M M B t u} * 24 \frac{h r}{\text { day }} * 330 \frac{\text { day }}{\text { year }}$

Cooling: $C_{\text {Cool }}=1.830 * 10^{8} \frac{B t u}{h r} * \frac{M M B t u}{10^{6} \text { Btu }} * \$ 1.50 \frac{1}{M M B t u} * 24 \frac{h r}{\text { day }} * 330 \frac{\text { day }}{\text { year }}$

Compressor Power: $C_{P r}=14781 \frac{k W}{d a y} * 1$ day $* 24 \frac{h r}{d a y} * \$ 0.05 \frac{1}{k W h} * 330 \frac{\text { day }}{\text { year }}$

Waste Water Treatment:

$$
C_{W W T}=94963 \frac{\mathrm{lb}}{\mathrm{hr}} * \frac{\mathrm{kg}}{2.2 \mathrm{lb}} * \frac{\text { tonne }}{1000 \mathrm{~kg}} * \$ 0.53 \frac{1}{\text { tonne }} * 24 \frac{\mathrm{hr}}{\text { day }} * 330 \frac{\mathrm{day}}{\text { year }}
$$

Labor: $C_{\text {labor }}=30$ employees $* \frac{\$ 60,000}{\text { employee }}+20$ employees $* \frac{\$ 100,000}{\text { employee }}$

Sales: $S=5000 \frac{\text { ton }}{\text { day }} * 2000 \frac{\mathrm{lb}}{\text { ton }} * \frac{\text { gal }}{6.6 \mathrm{lb}} * \$ 2.00 \frac{1}{\text { gal }} * 330 \frac{\text { day }}{\text { year }}$ 


\section{Process Analysis:}

$\mathrm{FCI}=\$ 1.3$ billion

$\mathrm{WCI}=0.15^{*} \mathrm{FCI}$

$\mathrm{TCI}=\mathrm{FCI}+\mathrm{WCI}$

$\mathrm{AFC}=(\mathrm{FCI}-$ Salvage value $) /$ Recovery Period

Salvage Value $=0.10 *$ FCI

Recovery Period $=10$ years

AATP $=($ Sales - AFC - AOC $) *(1-$ Tax Rate $)+$ AFC

Tax Rate $=30 \%$

$\mathrm{ROI}=\mathrm{AATP} / \mathrm{TCI}$

\section{Preprocessing Costs:}

Acid Gas Removal:

$C_{A G R}=23148 \frac{\text { lbmol feed }}{h r} * 379.5 \frac{s c f}{\text { lbmol feed }} * \frac{k s c f}{1000 s c f} * \$ 0.37 \frac{1}{k s c f} * 24 \frac{h r}{\text { day }} * 330$

Nitrogen Removal:

$$
C_{N_{2}}=23148 \frac{\text { lbmol feed }}{h r} * 379.5 \frac{s c f}{\text { lbmol feed }} * \frac{k s c f}{1000 s c f} * \$ 1.30 \frac{1}{k s c f} * 24 \frac{h r}{\text { day }} * 330 \frac{\text { day }}{\text { year }}
$$

C2 Credit: $S_{C 2}=1875 \frac{l b m o l}{h r} * 30.07 \frac{l b}{l b m o l} * \frac{g a l}{2.74 l b} * \$ 0.22 \frac{1}{\text { gal }} * 24 \frac{h r}{\text { day }} * 330 \frac{\text { day }}{\text { year }}$

C3 Credit: $S_{C 3}=532 \frac{l b m o l}{h r} * 44.10 \frac{l b}{l b m o l} * \frac{g a l}{4.22 l b} * \$ 0.97 \frac{1}{\text { gal }} * 24 \frac{h r}{\text { day }} * 330 \frac{\text { day }}{\text { year }}$

Total Preprocessing Cost: $C_{P}=C_{A G R+} C_{N_{2}}-S_{C 2}-S_{C 3}$ 


\section{Cost Differential:}

$$
\delta=\$ 3.50 \frac{1}{k s c f N G}-\frac{C_{N G}-C_{P}}{155.8 \frac{M M s c f}{d a y} * 1000 \frac{k s c f}{M M s c f} * 330 \frac{d a y}{y e a r}}
$$




\section{APPENDIX D}

\section{DETAILED CALCULATIONS FOR THE COMBINED HEAT AND POWER INTEGRATION}

\section{Heat Exchanger Network Data}

\begin{tabular}{|c|c|c|c|c|}
\hline Heat exchanger & $\mathbf{F C}_{\mathbf{p}}\left(\mathbf{B t u}{ }^{\mathbf{0}} \mathbf{F}\right)$ & In $\left(^{\mathbf{0}} \mathbf{F}\right)$ & Out $\left.\mathbf{(}^{\mathbf{0}} \mathbf{F}\right)$ & Duty (Btu/hr) \\
\hline O2-Heat & 82992 & 79 & 392 & 25976388 \\
\hline WGS-Heat & 329023 & 104 & 572 & 153982535 \\
\hline Heat-Rec & 436254 & 2319 & 104 & 966302898 \\
\hline Cool & 341257 & 614 & 104 & 174041053 \\
\hline MeOH Cool & 892803 & 464 & 302 & 144634153 \\
\hline Recycle Cool 1 & & 296 & 140 & 113424228 \\
\hline Recycle Cool 2 & & 140 & 113 & 13138160 \\
\hline
\end{tabular}

The first hot stream Heat-Rec can heat the two cold streams completely (it has enough Btu/hr and its temperature is higher than both cold streams).

Target for minimum heating utility $=0$

Target for minimum cooling utility $=1829.78-179.95=1,649.83 \mathrm{MM} \mathrm{Btu} / \mathrm{hr}$.

The cooling utility can be further reduced using cogeneration. Heat-Rec, Cool, and E1 can be used to generate steam which can be used in steam turbines to produce power.

After heat integration, remaining duty of Heat-Rec $=966-180=786 \mathrm{MM} \mathrm{Btu} / \mathrm{hr}$

This heat can be used until a temperature of $212{ }^{\circ} \mathrm{F}$.

Therefore, extractable heat from 2319 to $212=786 *(2319-212) /(2319-104)$

$$
=748 \mathrm{MM} \mathrm{Btu} / \mathrm{hr}
$$


Similarly, extractable heat from Cool $=174 *(614-212) /(614-104)=137 \mathrm{MM} \mathrm{Btu} / \mathrm{hr}$.

For E1, all of its heat is extractable because its outlet temperature is high enough $\left(302{ }^{\circ} \mathrm{F}\right)$.

Therefore, total extractable heat to be used in generating steam $=748+137+145=1,030 \mathrm{MM}$

$\mathrm{Btu} / \mathrm{hr}$.

Target for minimum cooling after steam generation/cogeneration $=1,650-1,030$

$$
=620 \mathrm{MM} \mathrm{Btu} / \mathrm{hr}
$$

$1 \mathrm{MM} \mathrm{Btu}=1.055^{*} 10^{6} \mathrm{~kJ}=1.055^{*} 10^{6} \mathrm{kWs}=1.055^{*} 10^{6} / 3600=293 \mathrm{kWh}$

Assuming that $30 \%$ of steam enthalpy will be converted to electric power:

Produced power $=0.3 * 1,030=309 \mathrm{MM} \mathrm{Btu} / \mathrm{hr}=309 * 293=90,537 \mathrm{kWh} / \mathrm{hr}=90,537$

$\mathrm{kW}=90,537 * 7920 \mathrm{hr} / \mathrm{yr}=717 \mathrm{MM} \mathrm{kWh} / \mathrm{yr}$

Assuming a value of $\$ 0.05 / \mathrm{kWh}$ :

Annual vale of electric energy $=717 * 10^{6} * 0.05==\$ 35.9 \mathrm{MM} / \mathrm{yr}$

Produced power $=90,537 \mathrm{KW}$

\section{Compressor details}

\begin{tabular}{|c|c|}
\hline Compressor & Power requirement \\
\hline COMP & 14528.7 \\
\hline CIRC & 17.7 \\
\hline
\end{tabular}

Total power demand $=14,529+18=14,547 \mathrm{~kW}$

Net power generation $=90,537-14,547=75,990 \mathrm{~kW}$

Annual value of net power generation $=75,990 \mathrm{~kW} * 7920 \mathrm{hr} / \mathrm{yr} * \$ 0.05 / \mathrm{kWh}$

$$
=\$ 30.1 \mathrm{MM} / \mathrm{y}
$$

